\title{
ブドウ‘ヒムロッド・シードレス’果粒の無核性発現 に関する解剖組織学的研究
}

\author{
王 近衛・堀内昭作 \\ 大阪府立大学農学部 591 堺市百舌鳥梅町
}

A Histological Study on the Seedlessness in 'Himrod Seedless' Grape

\author{
Jinwei $\mathrm{W}_{\text {ANG }}$ and Shousaku HoriuchI \\ College of Agriculture, University of Osaka Prefecture, Sakai, Osaka 591
}

\begin{abstract}
Summary
To clairfy the mechanism of seedlessness in 'Himrod Seedless' grape, histological comparisons were made between unseeded 'Himrod Seedless' and seeded 'Campbell Early' berries. The development of berry and seed, pollen fertility, pollen tube elongation in the ovary, internal morphology of the ovule, and the nuclear division in the endosperm and fertilized egg (zygote) were studied.

1. Berry and seed (ovule) development: The berries of 'Campbell Early' clearly exhibited a double-sigmoidal growth curve, whereas those of 'Himrod Seedless' lacked the second stage of berry growth and, therefore, did not reveal the same growth pattern. Seeds of 'Campbell Early' increased rapidly in size from about 1 week through 4 weeks after flowering which coincided with the first stage of fruit growth. The size remained constant thereafter until harvest. Seeds of 'Himrod Seedless' grew slightly for 2 weeks after anthesis and then stopped growing.

2. Parthenocarpic ability: The percent sets of parthenocarpic berries resulting from emasculated flowers were 23.3 for 'Himrod Seedless' and 15.9 for 'Campbell Early', which demonstrate that both cultivars can set berreis parthenocarpically. The weights of seedless berries of 'Himrod Seedless' and 'Campbell Early' were $60 \%$ and 15\% lighter, respectively, compared to those naturally pollinated berries.

3. Pollen fertility: The percentages of pollen which germinated on agar medium $(20 \% \mathrm{su}-$ crose, $1 \%$ agar) were 14.0 and 22.2 for 'Himrod Seedless' and 'Campbell Early', respectively. The percentages of pollen stained by acetocarmine were 90.4 and 45.6 for 'Himrod Seedless' and 'Campbell Early', respectively.

4. Pollen tube elongation in the ovary: The rate of pollen tube elongation in 'Himrod Seedless' was slightly slower than that of 'Campbell Early'. However, in both cultivars, $80 \%$ of the pollen tubes reached the ovules within $48 \mathrm{hr}$ after flowering.

5. Internal morphology of ovule and embryo sac: At anthesis, 'Himrod Seedless' ovules had an abnormally long inner integument and a larger micropyle compared to those of 'Campbell Early'. The embryo sac of many 'Himrod Seedless' ovules lacked the egg cell or the synergids, or exhibited degeneration of the egg apparatus. The percentage of ovules with these abnormalities was $88.4 \%$.

6. Nuclear division in the endosperm and embryo formation: In 'Campbell Early', freenuclear division of the endosperm began 3 days after anthesis, whereas nuclear division of the zygote began about 18 days later. In 'Himrod Seedless', 93.3\% of the endosperm did not exhibit free-nuclear division but degenerated. In the remaining $6.7 \%$ of the ovules, the endosperm nuclei divided only 2 or 3 times beginning 6 days after flowering. Cell division of
\end{abstract}

1989 年 10 月 24 日 受理. 本報告の一部は園芸学会昭和

63 年度秋季大会で発表した。 
the zygote was not observed.

We speculate that seedlessness in 'Himrod Seedless' berries is the result of abnormal double fertilization based on the high percentage of abnormal development of the embryo sac and egg apparatus and the limited nuclear division occurring in the endosperm. Polar nuclei may become fertilized but subsequent neclear divisions are abnormally low. This may hamper or limit the nutrient supply and lead to the degeneration of the zygote.

\section{緒言}

ブドウの無核果形成について Pearson(11)は‘トムソ ン・シードレス’および‘モヌッカ’などの無核ブドウは いずれも健全な花粉を有しているが，それらの胚珠に は異常な珠皮や胚のうを有するものが多く, 受精が行 われても胚乳組織が正常に発達しないため, 種子の形 成が行われないとしている，また，筆者ら(14)は“高尾” の無核果形成に関する研究から，その無核性の原因は 開花前に生じた胚珠部付近の胎座ならびに胚珠の内, 外皮の異常分裂から形態的異常をきたし，このことが 胚珠への花粉管侵入を妨げ，受精に影響を及ぼすもの と推察した.

しかし，ブドウ'ヒムロッド・シードレス（以下ヒム ロッドと略)の無核果形成の原因についてはまだほとん ど明らかにされていない，そこで本研究では，七ムロッ ド’の果粒と種子(胚珠)の発育, 単為結果性, 花粉稔 性, 子房内における花粉管伸長, 開花前後の胚珠と胚 のうの内部形態および胚乳核と受精卵の分裂などにつ いて組織学的に有核品種 ‘キャンベル・アーリー’ (以下 キャンベルと略)のそれらと比較し, 無核果形成機構の 解明を試みた。

\section{材料及び方法}

大阪府立大学農学部の围場で栽培されている 20 年生 無核品種“ヒムロッド”と有核品種“キャンベル’を供試 材料とした。

\section{1. 果粒と種子(胚珠)の発育調査}

開花期から成熟期まで 1 週間ごとに，マークをつけ ておいた樹上果 30 粒の横径と縦径をキャリパーで測定 した.また, 種子 (胚珠)の大きさは, 開花後 1 週間ご とに・キャンベル'はキャリパーで，“ヒムロッド'はパラ フィン切片をミクロメーターを用いて顕微鏡下で測定 した。

\section{2. 単為結果性の調査}

開花 3 日前に各品種当たり 10 花穂を選び，花らいの 除雄を行ったのち紙袋をかけて, 落果終了後(満開 20 日 後)に除袋を行って着果数を調查し, 単為結果性を検討 した。また，成熟時には果粒の大きさを調查した。

\section{3. 花粉 稔性の調查}

開花期に花粉を集め，アセトカーミン染色法による 花粉染色率および寒天培地 (ショ糖 $20 \%$, 寒天 $1 \%$ )で の発芽率を調査した (3). 発芽調查は, 花粉をスライド グラス上の培地に置床, $25^{\circ} \mathrm{C}$ で 6 時間培養後，コット ンブルーで染色，検鏡した．花粉管が花粉径の 2 倍以 上に伸長したものを発芽花粉とみなした，調査はいず れも 600 800 個の花粉について行った. なお，アセ卜 カーミンで染色された花粉粒は稔性花粉と判定した。

\section{4. 子房内の花粉管伸長の観察}

受粉後 $0,8,24,48,96$ 時間に各区 50 個の果粒(子 房)を採集し, FAA (70\%エタノール：酶酸：ホルマリ ン=90：5：5)液で固定したのち, 西山(8)の方法に より厚さ $15 \mu$ のパラフィン横断および維断切片を作製 した。これらの切片を Martin(6) および Majumder ら (5)の方法を参考にし， $0.1 \%$ アリンブルー $(0.1 \mathrm{~N}$ の $\mathrm{K}_{3} \mathrm{PO}_{4}$ 水溶液)を用い，室温で 4 時間染色した。花粉管 の行動は横断切片を用いて，落射蛍光顕微鏡(オリンパ ス BHC-RF-A，励起フィルター：UG-1，ダイクロ イックミラ：U, 吸収フィルター： $\left.\mathrm{L}_{420}\right)$ 下で花柱中央 部, 子房上部, 同中央部, 下部ならびに珠孔部の各位 置における花粉管数を数之, 縦断切片を用いて花粉管 の伸長状態を観察した。

\section{5. 胚珠内部形態の観 察}

開花 2 日前, 満開日および満開 1 か月後まで 3 日ご とに果粒を採取し, FAA 液で固定後, 厚さ $15 \mu$ のパ ラフィン連続縦断切片を作製した。切片は常法により キシロールでパラフィンを溶除後，4\%鉄みょうばん 水溶液で 12 時間処理し, その後 $0.5 \%$ へトキシリン 水溶液で 4 時間染色した。胚珠および胚のうの内部形 態および受精卵と胚乳核の分裂状態などについてはこ の切片を光学顕微鏡下で観察した.

\section{結 果}

\section{1. 果粒と種子(肧珠)の発育}

‘キャンベルの果粒は二重 S 字型曲線を描いて生長し, 満開 5 週間後から 6 週間後にかけて生長第 2 期に当た る生長の一時休止が認められた(第 1 図)。これに対し

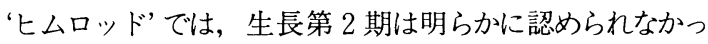


た.一方, 種子 (胚珠)の生長は, ‘キャンベル’では満開 約 5 週間後まで横径, 縦径ともに大きくなり，その後, 一定の值となった. ‘七ムロッド’では満開 2 週間後ま でごくわずかに大きくなったが，その後は生長を停止 した。

\section{2. 単為結果性}

除雄した“ヒムロッド’は $23.3 \%$ 着果率(単為結果 率)を示したが(第 1 表), 自然受粉の着果率 $35.2 \%$ に比 較して低かった，収穫時における前者の平均果粒重は $1.53 \mathrm{~g}$ で, 後者の果粒重の約 $60 \%$ であった. 対照とし て用いた有核品種の除雄した'キャンベル’゙も $15.9 \%$ の着果率がみられたが, 自然受粉の着果率 $51.8 \%$ に比 べて，はるかに低く，その果粒重は $0.65 \mathrm{~g}$ で自然受粉 のものの約 $15 \%$ と著しく小さかった. 両品種とも除雄 したものの果径指数 (横径/縦径) は自然受粉のものに 比較して大きかった.

\section{3. 花粉稔性}

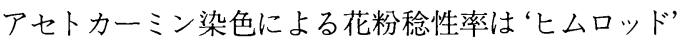
で $90.4 \%$, ‘キャンベル’で 45.6\%であり, 前者は後者 に比べて高かった，寒天培地上で発芽率は，“七ムロッ ド’で $14.0 \%$ ，‘キャンベル'で $22.5 \%$ ‘゙あり，前者は後 者よりやや低かった。

\section{4. 子房内の花粉管伸長}

子房内の各部位における花粉管数は両品種とも受粉 24〜48 時間後まで，時間の経過につれて増加する傾向 を示した(第 2 表)。すなわち, 花柱中央部位での'七ム ロッド’は‘キャンベル’に比べて調査時のすべてにおい て花粉管数が多かった。しかし，珠孔部位でのそれは， ‘ヒムロッド’が‘キャンベルよりやや少なかった。また， 両品種とも受粉 8 時間後には花粉管がすでに珠孔部に 到達し始め，48 時間後にはほぼ最高值を示したが，同 時期に花粉管が到達した胚珠の割合は両品種に大差が なかった.しかし，“ヒムロッド’は‘キャンベル’に比べ， 花粉管の胚珠内への侵入はやや遅れる傾向であった。

\section{5. 胚珠 の内部 形態}

開花時における両品種の胚珠はほとんどが完全に倒 生となっており, 珠心組織も完全に分化し, 発達して いた(第 2 図a).内珠皮と外珠皮についてみると, “キャ ンベル’ではともに正常なのに対して, ‘ムロッド’では ほとんどの外珠皮が正常であったが,内珠皮は異常に長 く(第 2 図 b), 珠孔部が正常なものに比べ大きく広がっ ているものの割合が $86.7 \%$ と多かった(第 3 表, 第 2 困 c). また, 開花時の ‘キャンベル'において大部分の肧 のうに二つの助細胞とその間にはさまれた卵細胞から なる卵装置と肧のうの中央部あるいは卵装置に接した ところに極核 (中央核) が認められた(第 2 図 d). ‘七ム ロッド’では，ほとんどの胚のうに極核(中央核)が存在 していたが, 卵細胞や助細胞を欠失しているもの, 助 細胞が異常に肥大したものや変形したものおよび完全 に退化したものが多く観察された(第 2 困e,f). その

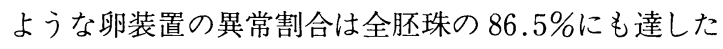
(第 4 表).さらに胚乳核の分裂についてみると(第 5 表) 'キャンベル'では開花 3 日後頃から分裂が始まり, その

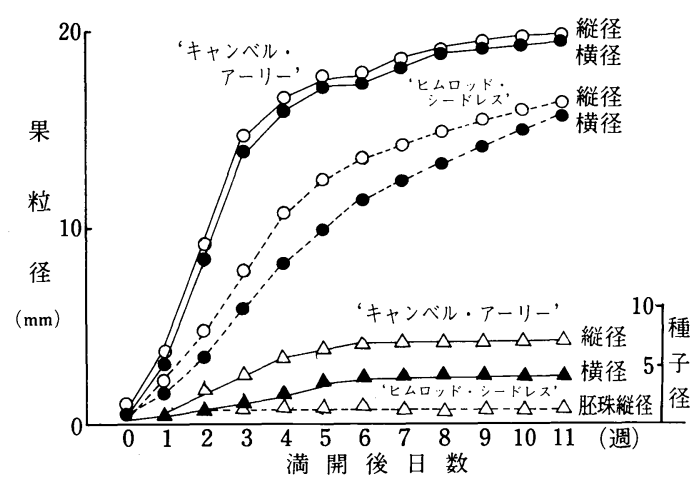

第 1 図. ‘ヒムロッド・シードレス’と‘キャンベル・アーリー’の 果粒および種子(胚珠)の生長曲線.

第 1 表. 除雄が‘ヒムロッド・シードレス’の着果に及ぼす影響.

\begin{tabular}{|c|c|c|c|c|c|c|c|c|c|}
\hline \multirow{2}{*}{ 品 } & \multirow{2}{*}{ 種 } & \multicolumn{3}{|c|}{1 花房当たり } & \multirow{2}{*}{$\begin{array}{l}\text { 着果率 } \\
(\%)\end{array}$} & \multicolumn{3}{|c|}{ 収穫時の平均果粒径 } & \multirow{2}{*}{$\begin{array}{l}\text { 収穫時の平坮 } \\
\text { 果粒重 (g) }\end{array}$} \\
\hline & & 全花 数 & 落果数 & 結果数 & & 横径 (mm) & 絍径 (mm) & 果径指数 ${ }^{2}$ & \\
\hline \multicolumn{2}{|c|}{ ヒムロッド } & $\begin{array}{l}182.5 \\
(410.8)^{y}\end{array}$ & $\begin{array}{c}140.0 \\
(266.0)\end{array}$ & $\begin{array}{c}42.5 \\
(144.8)\end{array}$ & $\begin{array}{c}23.3 \\
(35.2)\end{array}$ & $\begin{array}{c}13.2 \\
(15.9)\end{array}$ & $\begin{array}{c}12.9 \\
(16.3)\end{array}$ & $\begin{array}{c}1.02 \\
(0.98)\end{array}$ & $\begin{array}{c}1.53 \\
(2.58)\end{array}$ \\
\hline \multicolumn{2}{|c|}{ キャンベル } & $\begin{array}{c}121.2 \\
(202.0)\end{array}$ & $\begin{array}{l}101.9 \\
(97.4)\end{array}$ & $\begin{array}{c}19.3 \\
(104.6)\end{array}$ & $\begin{array}{c}15.9 \\
(51.8)\end{array}$ & $\begin{array}{c}9.7 \\
(19.1)\end{array}$ & $\begin{array}{c}9.2 \\
(19.6)\end{array}$ & $\begin{array}{c}1.05 \\
(0.97)\end{array}$ & $\begin{array}{c}0.65 \\
(4.47)\end{array}$ \\
\hline
\end{tabular}

z横径/縦径の值である.

y（）内の数字は自然受粉した場合の值である. 
第 2 表. 受粉後における ヒムロッド・シードレス’子房内での花粉管伸長 ${ }^{2}$.

\begin{tabular}{|c|c|c|c|c|c|c|}
\hline \multirow{2}{*}{ 品 } & \multirow{2}{*}{$\begin{array}{c}\text { 受粉後の時閒 } \\
\text { (洔間) }\end{array}$} & \multicolumn{4}{|c|}{ 子房内の各位置における花粉管数（本数） } & \multirow{2}{*}{$\begin{array}{l}\text { 花粉管が到達した } \\
\text { 胚珠の割合 }(\%)\end{array}$} \\
\hline & & 花柱中央部 & 子房上部 & 子房中部 & 珠孔部 & \\
\hline \multirow[t]{5}{*}{ ヒムロッド } & 0 & 0.1 & 0.0 & 0.0 & 0.0 & 0.0 \\
\hline & 8 & 35.0 & 10.3 & 2.8 & 0.8 & 30.8 \\
\hline & 24 & 40.1 & 13.6 & 3.4 & 1.0 & 53.2 \\
\hline & 48 & 38.0 & 14.2 & 6.3 & 2.1 & 80.4 \\
\hline & 96 & 38.5 & 13.8 & 6.6 & 2.0 & 78.3 \\
\hline \multirow[t]{5}{*}{ キャンベル } & 0 & 0.5 & 0.0 & 0.0 & 0.0 & 0.0 \\
\hline & 8 & 6.5 & 10.4 & 3.8 & 2.1 & 40.3 \\
\hline & 24 & 21.6 & 13.6 & 8.4 & 2.7 & 82.1 \\
\hline & 48 & 29.0 & 14.5 & 7.8 & 3.2 & 86.2 \\
\hline & 96 & 23.4 & 8.8 & 7.3 & 2.9 & 87.7 \\
\hline
\end{tabular}

z各処理に 50 倜の子房を用いて調査した。

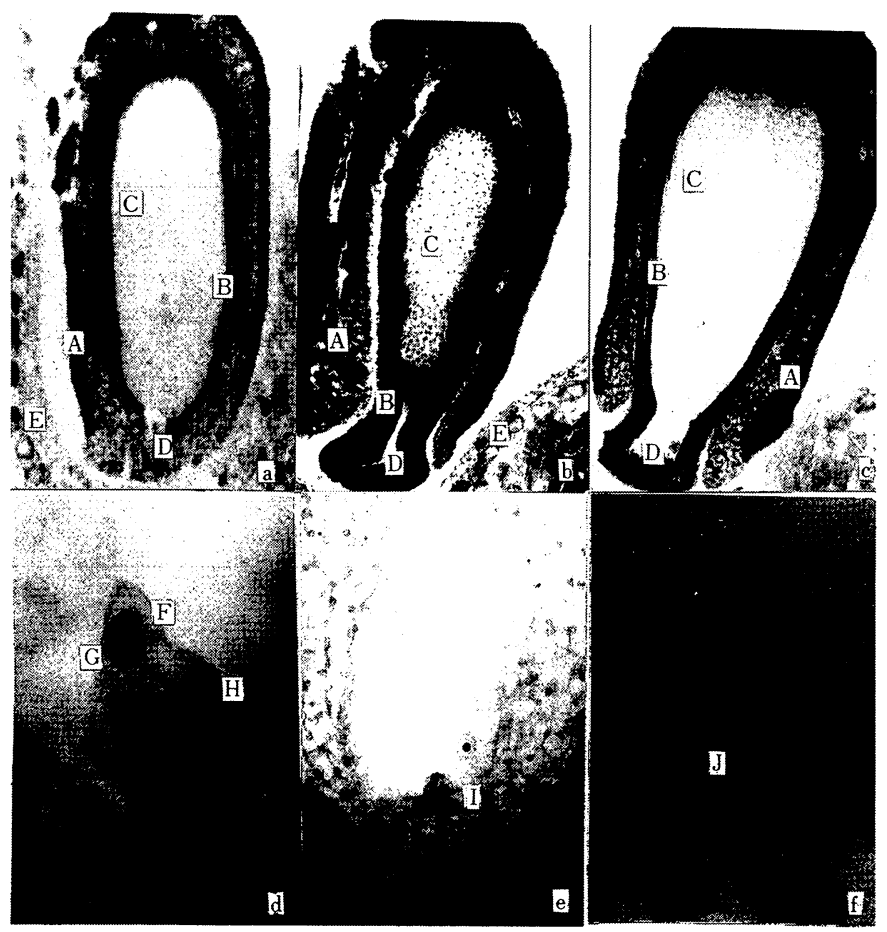

第 2 図. 満開時におけるブドウの胚珠の内部形態.

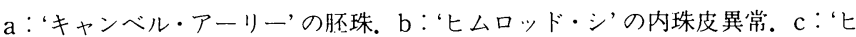
ムロッド・シードレス’の巨大珠孔。 d : ‘キャンベル・アーリー’の卵装置. $\mathrm{e}$, $\mathrm{f} ：$ ‘ムロッド・シードレス’の異常卵装置. $\mathrm{A}$ ：外珠皮。 B：内珠皮. B：内珠 皮. C : 珠心組織. D : 珠孔. $E$ ：胎座. $F$ ：中央核。 G：卵細胞. $H$ ：助細胞. $\mathrm{I} ：$ 退化した卵装置。J：卵装置細胞の異常。 
後も分裂を続けて，4 週間後頃になると胚のう内に胚 乳が充満した. 一方, ‘ヒムロッド'では, 開花後, ごく 少数の胚珠で $2 \sim 3$ 回の胚乳核分裂が観察されたが(第 3 図 b), 大部分の胚珠の胚乳核では分裂が認められず, そのまま退化した。また，“七ムロッド’の胚珠では萎縮 するものがみられ，それが開花 1 週間後頃から急速に 増加し， 3 週間後頃には $90 \%$ 以上にも達した(第 5 表, 第 3 図 c，d)。さらに受精卵についてみると“キャンベ ル`では開花約 3 週間後頃まで分裂が認められなかった が，その後，分裂を開始して，胚にまで分化・発達し た(第 4 図a〜e).しかし，“ヒムロッドではそのよう
な分裂が認められず，そのまま退化した(第 4 図 f h h).

\section{考察}

無核果を着生するブドウの品種中には‘ブラック・コ リンス’, ‘ホワイト・コリンス’などのように受精しな くても結果するもの(7)と'トムソン・シードレス’や‘モ ヌッカのように受粉・受精しないと結果しないもの 7 , 11)がある. 後者を偽単為結果といい, 前者の単為結果 と区別している(5). 本研究の結果, 無核品種の'ヒム ロッドは受精(受粉)なしで結果したことから単為結果 性を持つことが明らかになった，しかし，無受粉で得 られた収穫時の平均果粒重は自然受粉による正常果粒

第 3 表. 開花時における'七ムロッド・シードレス’の肧珠の内部形態

(調査した胚珠に対する割合，\%)。

\begin{tabular}{|c|c|c|c|c|c|c|c|c|c|}
\hline \multirow{2}{*}{ 品 } & \multirow{2}{*}{ 種 } & \multicolumn{2}{|c|}{ 胚珠の倒生状況 } & \multicolumn{2}{|c|}{ 珠心組織の発達状況 } & \multicolumn{2}{|c|}{ 外珠皮の分裂状態 } & \multicolumn{2}{|c|}{ 内珠皮の分裂状態 } \\
\hline & & 倒生 & 未倒生 & 発達 & 未発達 & 正常 & 異常 & 正常 & 異常 \\
\hline \multicolumn{2}{|c|}{ ヒムロッド } & 95.2 & 4.8 & 100.0 & 0.0 & 89.5 & 10.5 & 13.3 & 86.7 \\
\hline \multicolumn{2}{|c|}{ キャンベル } & 100.0 & 0.0 & 100.0 & 0.0 & 100.0 & 0.0 & 100.0 & 0.0 \\
\hline
\end{tabular}

2 各品種につき 200 個の胚珠を調查した。

第 4 表. 開花時における ヒムロッド・シードレス’の胚のうの内部形態

(調查した胚のうに対する割合，\%).

\begin{tabular}{|c|c|c|c|c|c|c|c|c|c|c|}
\hline \multirow{2}{*}{ 品 } & \multirow{2}{*}{ 種 } & \multicolumn{2}{|c|}{ 胚のうの有無 } & \multicolumn{2}{|c|}{ 極核（中央核）の有無 } & \multicolumn{2}{|c|}{ 卵装置の状況 } & \multicolumn{3}{|c|}{ 不完全卵装置の状態 } \\
\hline & & 有 & 無 & 有 & 無 & 完全 & 不完全 & 卵装置細胞の欠如 & 卵装置崩壊 & 完全退化 \\
\hline \multicolumn{2}{|c|}{ ヒムロッド } & 87.5 & 12.5 & 94.1 & 5.9 & 13.5 & 86.5 & 15.4 & 33.5 & 37.8 \\
\hline \multicolumn{2}{|c|}{ キャンベル } & 83.3 & 16.7 & 97.2 & 2.8 & 88.4 & 11.6 & 2.4 & 3.4 & 5.8 \\
\hline
\end{tabular}

z各品種につき 200 の胚のうを用いて調査した。

第 5 表. 開花後における ‘ヒムロッド・シードレス’の胚乳核分裂の状態z.

\begin{tabular}{|c|c|c|c|c|c|c|c|}
\hline \multirow{2}{*}{ 品 } & \multirow{2}{*}{ 開花後日数 } & \multicolumn{5}{|c|}{ 遊離胚乳核数 } & \multirow{2}{*}{$\begin{array}{c}\text { 胚珠の萎縮 } \\
(\%)\end{array}$} \\
\hline & & 1 & $2 \sim 4$ & $5 \sim 8$ & $9 \sim 16$ & 16 以上 $(\%)$ & \\
\hline \multirow[t]{7}{*}{ ヒムロッド } & 0 & 97.1 & 2.9 & 0.0 & 0.0 & 0.0 & 8.2 \\
\hline & 3 & 97.4 & 2.6 & 0.0 & 0.0 & 0.0 & 11.1 \\
\hline & 6 & 95.5 & 4.5 & 0.0 & 0.0 & 0.0 & 30.3 \\
\hline & 9 & 92.8 & 7.1 & 0.0 & 0.0 & 0.0 & 60.7 \\
\hline & 12 & 87.7 & 5.6 & 6.7 & 0.0 & 0.0 & 86.5 \\
\hline & 15 & 90.4 & 6.5 & 3.1 & 0.0 & 0.0 & 81.8 \\
\hline & 21 & 94.1 & 5.9 & 0.0 & 0.0 & 0.0 & 93.3 \\
\hline \multirow[t]{7}{*}{ キャンベル } & 0 & 95.2 & 4.8 & 0.0 & 0.0 & 0.0 & 6.8 \\
\hline & 3 & 89.7 & 10.2 & 0.0 & 0.0 & 0.0 & 3.9 \\
\hline & 6 & 71.1 & 26.3 & 2.6 & 0.0 & 0.0 & 21.7 \\
\hline & 9 & 11.6 & 81.4 & 4.7 & 2.3 & 0.0 & 17.1 \\
\hline & 12 & 10.0 & 70.0 & 10.0 & 5.0 & 5.2 & 11.2 \\
\hline & 15 & 4.1 & 28.6 & 44.9 & 12.2 & 10.2 & 14.4 \\
\hline & 21 & 0.0 & 0.0 & 4.1 & 6.1 & 89.7 & \\
\hline
\end{tabular}

z 各処理につき 40 個の子房を用いて調査した。 

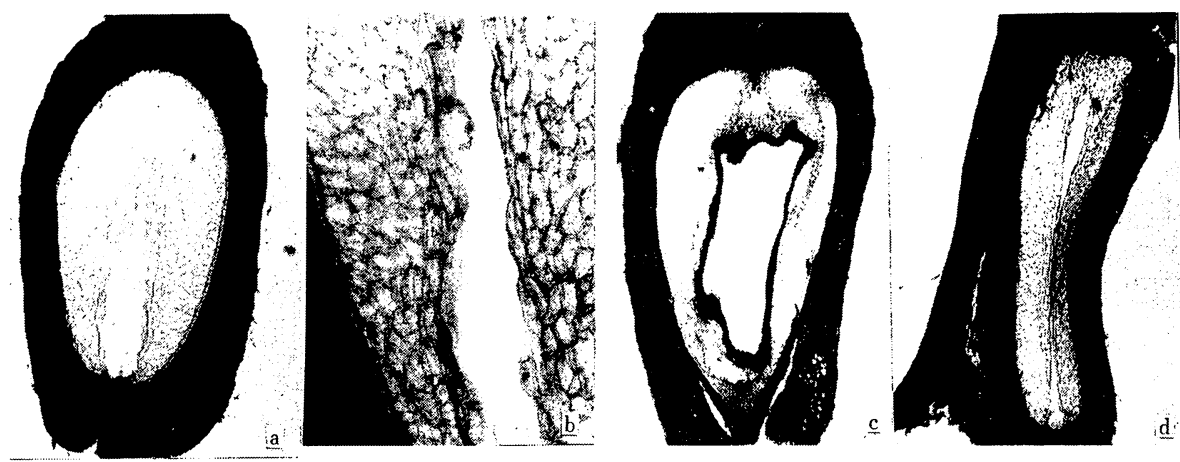

第 3 図. ‘ヒムロッド・シードレス’胚珠の内部形態. $\mathrm{a}$ : 満開時の胚珠. b : 肧乳核(満開 10 日後). c, d : 萎縮した胚珠(満開 20 日後).

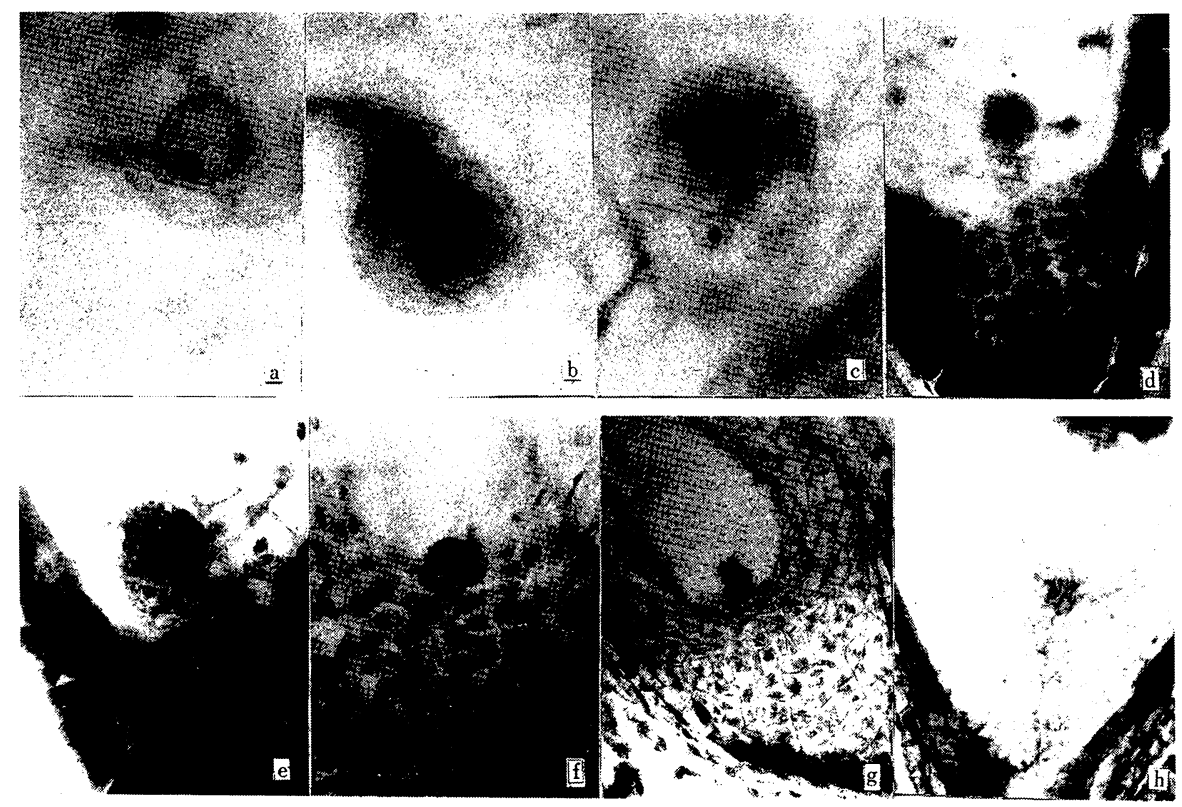

第 4 図. ‘キャンベル’・アーリー’およU゙‘ヒムロッド・シードレス’の胚発生状態.

$\mathrm{a}$ : ‘キャンベル・アーリ一’の受精卵(満開 10 日後)。b : ‘キャンベル・アーリー’の受精卵の第 1 回分裂 (満 開 20 日後). c e e:‘キャンベル・アーリー’の胚. f h h : ‘ヒムロッド・シードレス’の退化した卵装置.

重に比べ軽かったことは，受粉に関連して起こる何ら かの物理・化学的要因がその後の果粒の生長に影響を 及ぼすことを示唆している. Coombe (1960)は単為結果 しやすいブドウのやくおよび花粉中にジベレリンが存 在すると報告している(1)，おそらく“ヒムロッド’の花 粉中にもジベレリンなどの植物ホルモンが含まれてい るものと推定され，それらのホルモンが花粉管の伸長 とともに子房内に移動し, その後の果粒の生長に影響
を及ぼすものと考えられる。一方，花粉管の伸長によ る物理的刺激が花柱あるいは子房内で果粒の生長を促 す物質の合成，代謝を活発にし，その生長に影響を与 えるとも考えられる。

花粉稔性に関してブドウでは花粉の発芽率が $6 \%$ 以 上であれば受精が行われ，稔性種子を含む果粒が得ら れるとされている(4). 本実験において，“ヒムロッド' のアセトカーミン染色法による花粉稔性率は, 有核品 
種の‘キャンベル’よりむしろ高く，また，花粉発芽率 も $14 \%$ であったことから，その種子を形成しない原因 は花粉の不稔によるものとは考えにくい，さらに，花 粉管の子房内部への侵入についてみると， ‘ムムロッド” は花粉管の伸長が‘キャンベル’よりやや遅れる傾向て あったが，受粉 48 時間後に花粉管がすでに $80 \%$ 以上も 胚珠内に到達していた。この結果は，受粉は行われて いることを示している，花粉管が胚珠内へ到達する日 数については, リンゴでは $3 \sim 5$ 日(13)，モモでは 12〜24 日（2）とされており，それらに比べるとブドウ'ヒ ムロッド’や‘キャンベル’では受粉から受精に至る所要 時間が 2 日とはるかに短い結果となった。

一般に被子植物では，花粉管が胚のうに到達すると 2 個の精核がそれぞれ卵細胞と極核 (中央核)に合体し， 重複受精が行われる。また，胚乳核の分裂開始は，受 精が完了したことを示す一つの指標とされている $(9,4)$. 多くのブドウの有核品種では, 胚乳核の分裂は受粉 2 ～4 日後に開始すると報告されている $(4,7,9)$. 本実験 においても，“キャンベル’では受粉 3 日後に胚乳核の分 裂か観察され，従来の研究と一致した。一方，“七ムロッ ド’の胚珠で胚乳核の分裂が認められたものの，大部分 の胚珠では，胚乳核の分裂が認められなかった。また， 分裂の認められた胚乳核でも $2 \sim 3$ 回の分裂だけで, それ以上の分裂が観察されなかった。これらのことか ら“ヒムロッド’の大部分の胚珠では受精が行われない ものと考えられる。

ブドウにおいて $2 \sim 7$ 細胞の胚に発育する所要時間 は品種により異なり，‘フレドニア’は2 23 日，“エリエ’は 10〜12 日，“ゴールデン・マスカット’は19２0日，‘コ ンコードは 14 16 日であると報告されている(12). ‘キャンベル’の胚発育は‘エリエ’，‘コンコード’より遅 く, ‘フレドニア’と'ゴールデン・マスカット’とほぼ一 致している。しかし，“ヒムロッドでは受精卵の分裂が 認められず，そのまま退化した。不受精の胚珠では胚 分化が行われないが，受精したと考えられたごく少数 の胚珠においても，胚の分化は認められなかった。こ れは胚乳核の早期分裂停止とも関連していると思われ る。この胚乳核の早期分裂停止の原因は明らかにしえ なかったが, 一つの原因としては開花直後における内 生植物ホルモンなどの不均衝が生理的な影響を及ぼす ものと推察される。

有核ブドウ品種では，開花時の正常な胚のう内に二 つの助細胞と卵細胞からなる卵装置と極核 (中央核) が 存在している (9). 本実験でも有核品種の“キャンベル”
では，既報 (9) と同様であったが，無核品種の‘ヒムロッ ド’では極核 (中央核)の存在がほとんとんどの胚珠で認 められたものの，多くの異常な卵細胞や助細胞が認め られた。したがって，“ヒムロッド”の無核性は卵細胞や 助細胞の異常に基づく不受精が主原因と考之られた。

\section{摘 要}

ブドウ・ヒムロッド・シードレス(ヒムロッドと略)’の 無核果形成機構を組織学的に明らかにするため，果粒 および種子の発育，花粉稔性，子房内での花粉管の伸 長，開花後の胚珠の内部形態ならびに開花後の胚乳核, 受精卵の分裂などを有核品種の‘キャンベル・アーリー (キャンベルと略)'のそれと比較しながら検討した。

1. 果粒と種子(肧珠)の発育：“キャンベル’の果粒は 二重 S 字型生長曲線を示したが，“ヒムロッド’では，生 長の第 2 周期が認められず，明確な二重 $\mathrm{S}$ 字型生長曲 線を示さなかった。‘キャンベル’の種子(胚珠)は開花 1 週間後より果粒生長第 1 期完了時 (開花 4 週間後) ま で急激に生長したが，その後は成熟時まで一定の值を 示した。 ‘ムロッド’の種子(胚珠) は, 開花 2 週間後 までわずかに生長したが，その後は生長を停止した。

2. 単為結果性：無受粉による果実の着果率 (単為結 果率) は“ヒムロッド’で $23.3 \%$ ，“キャンベル'で $15.9 \%$ であった．両品種とも単為結果性を持つことが認めら れたが，果粒の大きさは自然受粉果に比べ，小さかっ た。

3. 花粉稔性：寒天培地上での‘ヒムロッド’の花粉発 芽率は $14.0 \%$ ，“キャンベル’のそれは $22.2 \%$ であった。 アセトカーミン染色法による稔性花粉は，前者が $90.4 \%$ ，後者が $45.6 \%$ を示した。

4. 子房内の花粉管伸長：“比ッド”の花粉管の伸 長速度は‘キャンベル’に比較してやや遅かった。しか し，両品種とも受粉 48 時間後には花粉管が約 8 割の胚 珠に到達し，両品種間に明らかな差異は認められなかっ た.

5. 胚珠の内部形態：開花時において，“七ムロッド' の内珠皮は異常に長く，珠孔も大きいことが観察され た。また，卵細胞や助細胞の欠失したものや，卵装置 が完全に退化したものが多く認められ，全調查胚珠の 88.4\%がそのような異常を示す胚珠であった。

6. 胚乳核の分裂および胚発生：“キャンベル’では, 受粉 3 日後から胚乳核が分裂し，受精卵の分裂は受粉 約 3 週間後からであった。一方，“七ムロッドてでは， 93.3\%の胚珠で胚乳核の分裂が認められず，そのまま 退化した。 $6.7 \%$ 胚珠は開花 6 日後頃から分裂を始め 
たが, 2 ～ 3 回の分裂を行った後，分裂を停止した. 受精卵の分裂は観察できなかった。

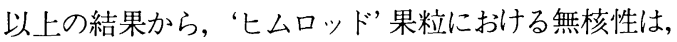
受粉後の伸長花粉管が胚珠にまで到達するものの, 大 部分の胚珠で胚のうおよび卵装置に異常が生じている ため，受精にまで至らないことが原因と考えられた。 しかし, ごく少数の胚珠では肧乳核の分裂が認められ たので，受精が行われたものと解されるが，その後に おける胚乳核の異常分裂により受精畉は分裂が妨げら れ，そのまま退化したものと考えられた。

\section{引用文献}

1. Coombe, B. G. 1960. Relationship of growth and development to changes in sugars, auxins and gibberellins of Vitis vinifera. Plant Physiol. $35: 241-250$.

2. 石田雅士・稲葉昭次 - 工藤正義 - 傍島善次. 1979. モモの受精に関する基礎的研究. 園芸学 研究集録 9：19-27.

3. 小林 章 - 岡本五郎. 1967. Muscat of Alexandria における摘心およびホウ素の葉面散布が 体内栄養ならびに結実に及ぼす影響。(第 1 報). 園学雑. 36:31-35.

4. 小松春喜. 1987. ブドウ ‘巨峰’の花振いに関す る研究. 大阪府立大学学位論文.

5. Majumder, S. K., K. R. Kerns, J. L. Brewbakar and G. A. Johannessen. 1964 Assessing selfincompatibility in pineapple by a pollen fluorescence techique. Proc. Amer. Soc. Hort. Sci. $84: 217-223$.

6. Martin, F. W. 1959. Staining and observing pollen tubes in the style by means of fluorescense. Stain Tech. 34 : 125-127.

7. 中川昌一. 1978. 果樹園芸原論. p. 107, 175, 235。養賢堂。東京。

8. 西山市三. 1961. 細胞遗伝学研究法. p. 132145. 養賢堂. 東京.

9. 岡本五郎・今井俊治１982．ブドウ'マスカッ ト・オブ・アレキサンドリア’の結実に関する組 織形態学的研究. 園学雑. $50: 436-444$.

10. Oцmo, H. P. 1936. Pollination and the setting of fruit in the Black Corinth grape. Proc. Amer. Soc. Hort. Sci. 34 : 402-404.

11. Pearson, H.M. 1932. Parthenocarpy and seed abortion in Vitis vinifera. Proc. Amer. Soc. Hort. Sci. $29: 169-175$.

12. Pratt, C. 1971. Reproductive anatomy in cultivated grapes - A review. Amer. J. Enol. Viticul. 22:92-109.

13. 島 善隣. 1937. リンゴ花器の内部形態と花粉 管の行動における $2 ， 3$ の観察．農及園。12： 21-29.

14. 王 近衛・堀内昭作・湯田英二. 1988。ブドウ ‘高尾’の不受精の機構に関する形態学的観察. 園学要旨. 昭和 63 秋：200-201. 